\title{
UJI DAYA HAMBAT EKSTRAK ETANOL DAUN SUJI (Pleomele Angustifolia N. E. Brown) TERHADAP PERTUMBUHAN BAKTERI Staphylococcus aureus
}

\section{INHIBITION TEST OF ETHANOL EXTRACT SUJI LEAVES (Pleomele Angustifolia N. E. Brown ) TOWARD TO GROWTH OF BACTERIA Staphylococcus aureus}

\author{
Didi Rohadi, Didin Ahidin, Desiyanti \\ Sekolah Tinggi Farmasi Muhammadiyah Cirebon \\ Jl.Cideng Indah No. 3 Cirebon \\ Email :didiaskun2@gmail.com
}

Submitted : 30 Januari 2021 Reviewed : 13 Februari 2021 Accepted : 15 Maret 2021

\begin{abstract}
ABSTRAK
Penyakit infeksi merupakan jenis penyakit yang paling banyak diderita oleh penduduk di negara berkembang, termasuk Indonesia. Salah satu penyebab penyakit infeksi adalah bakteri. Penyakit infeksi di Indonesia kebanyakan diobati dengan menggunakan antibiotik. Alternatif untuk mengobati infeksi yaitu dengan memanfaatkan bahan-bahan alami dari tanaman obat. Salah satu tanaman yang berpotensi sebagai obat herbal adalah tanaman daun suji (Pleomele Angustifolia N. E. Brown). Tujuan dari penelitian ini adalah untuk mengetahui apakah ekstrak etanol daun suji (Pleomele Angustifolia N. E. Brown) pada konsentrasi 10\%, 20\%, 40\% dan 80\% dapat menghambat dan bagaimana pengaruh peningkatan konsentrasi ekstrak etanol terhadap daya hambat pertumbuhan bakteri Staphylococcus aureus. Untuk itu dilakukan penelitian dengan menggunakan metode uji daya hambat difusi cetak lubang ekstrak etanol daun suji (Pleomele Angustifolia N.E.Brown) terhadap bakteri Staphylococcus aureus. Daun suji yang dijadikan ekstrak kental dengan konsentrasi $10 \%, 20 \%, 40 \%$, dan $80 \%$. Hasil penelitian yang didapat menunjukkan hanya ekstrak etanol daun suji pada konsentrasi $80 \%$ saja yang dapat menghambat pertumbuhan bakteri Staphylococcus aureus dengan zona hambat 1,42 mm. Kontrol positif yang dijadikan pembanding adalah amoxicillin injeksi $0,001 \%$ membentuk diameter rata-rata $2,23 \mathrm{~mm}$.
\end{abstract}

Kata kunci: Daun suji (Pleomele Angustifolia N. E. Brown), Staphylococcus aureus, difusi cetak lubang.

\section{ABSTRACT}

Infectious diseases are still the most common type of illness affecting people in developing countries, including Indonesia. One of the causes of contagious disease is bacteria. Most infectious diseases in Indonesia treated using antibiotics. An alternative to treating infections is by utilizing natural ingredients from medicinal plants. One of the plants with the potential as herbal medicine is the suji leaf plant (Pleomele Angustifolia N. E. Brown). The purpose of this study was to determine whether the ethanol extract of suji leaves (Pleomele Angustifolia N. E. Brown) at a concentration of $10 \%, 20 \%, 40 \%$, and $80 \%$ can inhibit and how the effect of increasing the concentration of ethanol extract on the inhibition of growth of Staphylococcus aureus bacteria. For this reason, a study carried out using the diffusion inhibition test method of the ethanol extract of suji leaves (Pleomele Angustifolia N. E. Brown) against Staphylococcus aureus bacteria. Suji leaves made into thick extracts with concentrations of $10 \%, 20 \%, 40 \%$, and $80 \%$. The results showed that only suji leaf ethanol extract at a concentration of $80 \%$ could inhibit Staphylococcus aureus 
bacteria's growth with an inhibition zone of $1.42 \mathrm{~mm}$. The positive control used for comparison was amoxicillin injection of $0.001 \%$, forming an average diameter of $2.23 \mathrm{~mm}$

Keyword: Leaves of suji (Pleomele Angustifolia N. E. Brown), Staphylococcus aureus, inhibition.

\author{
Penulis Korespondensi : \\ Didi Rohadi \\ Sekolah Tinggi Farmasi Muhammadiyah Cirebon \\ Jl.Cideng Indah No. 3 Cirebon \\ Email : didiaskun2@gmail.com
}

\title{
PENDAHULUAN
}

Penyakit infeksi masih merupakan jenis penyakit yang paling banyak diderita oleh penduduk di negara berkembang, termasuk Indonesia (Radji, 2008). Salah satu penyebab penyakit infeksi adalah bakteri. Bakteri merupakan mikroorganisme yang tidak dapat dilihat dengan mata telanjang, tetapi hanya dapat dilihat dengan bantuan mikroskop (Radji, 2008). Bakteri berukuran 0,5-5 $\mu \mathrm{m}$ dan dapat dilihat melalui mikroskop cahaya dengan perbesaran minimal 40 kali dan perbesaran maksimal 1000 kalinya. Salah satu agen penyebab infeksi adalah bakteri Staphylococcus aureus (Jawetz dkk, 2010). Penyakit infeksi di Indonesia kebanyakan diobati dengan menggunakan antibiotik. Penggunaan antibiotik yang tidak tepat menyebabkan peningkatan resistensi. Bila telah terjadi resistensi maka akan lebih sulit untuk dilakukan upaya pengobatan maka diperlukan terapi alternatif untuk mengobati infeksi yaitu dengan memanfaatkan bahan-bahan alami dari tanaman obat (Ibrahim dkk, 2011).

Indonesia merupakan negara tropis yang mempunyai biodiversitas tinggi, kaya akan flora maupun fauna. Indonesia mempunyai ribuan jenis tanaman yang dapat dimanfaatkan dengan baik dan harus dilestarikan. Dari beberapa tanaman tersebut dapat dimanfaatkan sebagai tanaman obat (Peoloengan dalam Alafiah, 2015). Sebagian peneliti sampai saat ini masih terus melakukan penelitian untuk mencari bahan baku obat dari sumber daya alam (Radji dalam alafiah, 2015). Salah satu tanaman yang berpotensi sebagai obat herbal adalah tanaman daun suji (Pleomele Angustifolia N. E. Brown). Menurut Andriani dkk, (2018) ekstrak etanol daun suji memiliki aktivitas antibakteri terhadap Staphylococcus mutans dengan diameter daya hambat $4 \mathrm{mg} /$ disk sebesar $12,9 \mathrm{~mm}, 5 \mathrm{mg} /$ disk sebesar $14,9 \mathrm{~mm}$, dan $6 \mathrm{mg} /$ disk sebesar $15,2 \mathrm{~mm}$.

Tanaman suji (Pleomele Angustifolia N. E. Brown) adalah salah satu tanaman obat yang mengandung saponin, flavonoid dan polifenol yang memiliki aktivitas antibakteri (Andarini dkk, 2012). Tanaman ini dapat digunakan untuk mengobati penyakit diare dan disentri yang disebabkan oleh infeksi bakteri diantaranya Staphylococcus aureus dan Shigella sp (Andarini dkk, 2012). Menurut Andarini dkk, (2012) ekstrak etanol daun suji memiliki aktivitas antibakteri terhadap Staphylococcus aureus dan Shigella sp pada konsentrasi 25\% terkait kandungan flavonoid, saponin, dan tannin. Pada penelitian kali ini menggunakan ekstrak etanol daun suji pada konsentrasi 10\%, 20\%, 40\%, dan $80 \%$ dikarena penelitian uji daya hambat ekstrak etanol daun suji terhadap pertumbuhan bakteri Staphylocooccus aureus masih belum banyak dilakukan sehingga perlu diteliti dalam interval yang lebar. Penggunaan etanol sebagai pelarut ekstraksi dikarenakan etanol merupakan pelarut universal yang mampu melarutkan hampir seluruh jenis metabolit sekunder yang mempunyai berat molekul rendah seperti flavonoid, saponin, dan alkohol; tidak bersifat racun serta aman untuk digunakan . Staphylococcus aureus berbentuk bulat atau lonjong jenis bakteri yang tidak bergerak, tidak bersimpai, tidak berspora, bersifat aerob dan merupakan bakteri gram positif (Gupte, 1990). Penelitian ini bertujuan untuk mengetahui apakah ekstrak etanol daun suji (Pleomele Angustifolia N. E. Brown) pada konsentrasi 10\%, 20\%, 40\% dan 80\% dapat 
menghambat dan bagaimana pengaruh peningkatan konsentrasi ekstrak etanol terhadap daya hambat pertumbuhan bakteri Staphylococcus aureus.

\title{
METODE PENELITIAN
}

\section{Jenis Penelitian}

Jenis penelitian ini menggunakan metode eksperimen yaitu melakukan percobaan dan pengamatan pada objek yang sedang diteliti untuk mengetahui daya hambat ekstrak etanol daun suji (Pleomele Angustifolia N. E. Brown) dengan konsentrasi 10\%, 20\%, 40\%, 80\% terhadap pertumbuhan bakteri Staphylococcus aureus.

\begin{abstract}
Alat dan Bahan
Alat pada penelitian ini adalah: Autoklaf (Model 25 x Eledricl 38 max); timbangan analitik; bejana (wadah maserasi); gelas ukur 10ml (Pyrex); $100 \mathrm{ml}$ (Pyrex); beacker glass $100 \mathrm{ml}$ : beacker glass $150 \mathrm{ml}$; cawan uap; waterbath; vacum rotary evaporator (IKA); labu ukur $10 \mathrm{ml}$ (Iwaki); Erlenmeyer $250 \mathrm{ml}$ (Pyrex); Bunsen; jarum ose; cawan petri (pyrex 90$100 \mathrm{~mm}$ ); tabung reaksi (Pyrex 12 x $75 \mathrm{~mm}$ ); incubator (Memmert); tipcon; spuit injeksi $1 \mathrm{cc}$ (Terumo syringe); jangka sorong (Krisbow); mikropipet $20 \mu \mathrm{l}$ (Baeco Germany).

Bahan pada penelitian ini adalah daun suji segar; etanol 70\% (Bratachem); aqua pro injeksi (Kimia Farma); nutrient agar (Oxoid); aqua dest (Sanbe Farm); bakteri Staphylococcus aureus; amoxicillin injeksi (Sanbe Farma); bahan untuk desinfektan (wipol).
\end{abstract}

\section{Jalannya Penelitian}

1. Pembuatan Simplisia Daun Suji (Pleomele Angustifolia N. E. Brown)

Daun suji (Pleomele angustifolia N. E. Brown) yang telah dipilih kemudian dicuci bersih dengan air mengalir, kemudian dipotong kecil-kecil, daun suji yang telah dibersihkan di masukkan ke dalam oven dengan suhu $40^{\circ}$ selama 24 jam. Kemudian timbang sebanyak $200 \mathrm{~g}$.

2. Pembuatan Ekstrak Etanol Daun Suji (Pleomele Angustifolia N. E. Brown)

Timbang simplisia daun suji seberat $200 \mathrm{~g}$, direndam didalam maserator yang berisi cairan penyari yaitu etanol $70 \%$ sebanyak $1500 \mathrm{ml}$ selama 3 hari dan sesekali diaduk. Setelah 3 hari saring dan diperas dicuci ampas dengan cairan penyari $500 \mathrm{ml}$, kemudian wadah ditutup, biarkan ditempat sejuk terlindung dari cahaya. Ekstrak dipekatkan dengan rotary evaporator, kemudian dilanjutkan dengan penguapan di atas waterbath sampai diperoleh ekstrak kental. Selanjutnya menghitung rendemen. Ekstrak yang diperoleh kemudian dibuat pengenceran dengan konsentrasi 80\%, 40\%, 20\%, 10\% v/v.

3. Pembuatan kontrol positif antibiotik amoxicillin $0,001 \%$ dan kontrol negatif etanol $70 \%$.

4. Pembuatan Media Untuk Cawan Petri

Timbang Nutrient Agar seberat 1,4 gram. Campurkan dengan aquadest sebanyak $70 \mathrm{ml}$ dalam beakcer glass. Panaskan nutrient agar diatas api kecil sampai jernih dan homogen, tuangkan media kedalam tabung reaksi, kemudian tutup dengan kapas berlemak, bungkus dengan kertas perkamen dan ikat dengan benang kasur. Sterilkan dengan autoklaf pada suhu $121^{\circ} \mathrm{C}$ selama 15 menit.

5. Pembuatan Media Agar Miring

Timbang Nutrient Agar seberat 0.14 gram. Campurkan dengan aquadest sebanyak $5 \mathrm{ml}$ dalam beacker glass aduk sampai larut. Panaskan nutrient agar diatas api kecil sampai jernih dan homogen, tuangkan media kedalam tabung reaksi, kemudian tutup dengan kapas berlemak, bungkus dengan kertas perkamen dan ikat dengan benang kasur. 
Sterilkan dengan autoklaf pada suhu $121^{\circ} \mathrm{C}$ selama 15 menit. Setelah steril, media miringkan dengan kemiringan $10^{\circ} \mathrm{C}$ dan biarkan memadat.

6. Prosedur Uji Daya Hambat Metode DIfusi Cetak Lubang

Ambil sebanyak $1 \mathrm{ml}$ suspensi bakteri dengan spuit, masukan ke dalam erlenmeyer yang berisi ml media nutrient agar steril (hangat) goyang sampai homogen. Tuangkan Media Nutrient Agar ke dalam 3 cawan petri masing-masing $20 \mathrm{ml}$, kemudian biarkan sampai memadat. Sebelum mencetak lubang, terlebih dahulu permukaan daerah cawan petri ditandai dengan stiker atau label (kontrol positif, kontrol negatif, konsentrasi $10 \%$, $20 \%, 40 \%$, dan $80 \%$ ) untuk menempatkan posisi pencadangan yang akan ditetesi dengan variasi konsentrasi. Setelah ditandai cetak lubang dengan alat pencetak lubang yang sudah diflambir. Lubang pada media diisi dengan ekstrak etanol daun suji dengan berbagai konsentrasi ke dalam lubang sebanyak 20 mikroliter $(0,02 \mathrm{ml})$ dengan pipet mikro, kontrol positif dan kontrol negatif. Setelah itu dibiarkan selama 30 menit, lalu masukan ke dalam inkubator pada suhu $33-37^{\circ} \mathrm{C}$ selama $18-24$ jam. Lihat dan ukur diameter hambatnya dengan menggunakan jangka sorong.

7. Pembacaan Hasil

Pembacaan hasil dilakukan setelah diinkubasi selama 24 jam dengan cara melihat. daerah bening di sekeliling lubang sumuran yang mengandung infus daun salam sebagai daerah hambat pertumbuhan bakteri Staphylococcus aureus. Diameter hambatan tersebut diukur dengan menggunakan jangka sorong

\section{Analisa Data}

Metode analisis data yang digunakan adalah metode eksperimental yaitu berupa data kuantitatif. Data disajikan dalam bentuk tabel dan persentase.

\section{HASIL DAN PEMBAHASAN}

Tabel I. Rata-rata diameter hambat ekstrak etanol daun suji (Pleomele Angustifolia N.E. Brown) konsentrasi $10 \%, 20 \%, 40 \%$, dan $80 \%$ terhadap pertumbuhan Staphylococcus aureus

\begin{tabular}{|c|c|c|c|c|c|c|}
\hline \multirow{3}{*}{ Replikasi } & \multicolumn{6}{|c|}{ Diameter Daerah Hambat $(\mathrm{cm})$} \\
\hline & \multirow{2}{*}{$\begin{array}{l}\text { Kontrol } \\
\text { positif } \\
\text { Amoxicilin } \\
0,001 \%\end{array}$} & \multirow{2}{*}{$\begin{array}{l}\text { Kontrol } \\
\text { negatif } \\
\text { Etanol } 70 \%\end{array}$} & \multicolumn{4}{|c|}{ Konsentrasi ekstrak } \\
\hline & & & $10 \%$ & $20 \%$ & $40 \%$ & $80 \%$ \\
\hline 1 & 2,22 & 0,6 & 0,6 & 0,6 & 0,6 & 1,45 \\
\hline 2 & 2,21 & 0,6 & 0,6 & 0,6 & 0,6 & 1,42 \\
\hline 3 & 2,28 & 0,6 & 0,6 & 0,6 & 0,6 & 1,40 \\
\hline Jumlah & 6,71 & 1,8 & 1,8 & 1,8 & 1,8 & 4,27 \\
\hline Rata-rata & 2,23 & 0,6 & 0,6 & 0,6 & 0,6 & 1,42 \\
\hline SD & 0,03 & 0 & 0 & 0 & 0 & 0,02 \\
\hline
\end{tabular}

Keterangan: Diameter lubang $=0,6 \mathrm{~cm}$ 


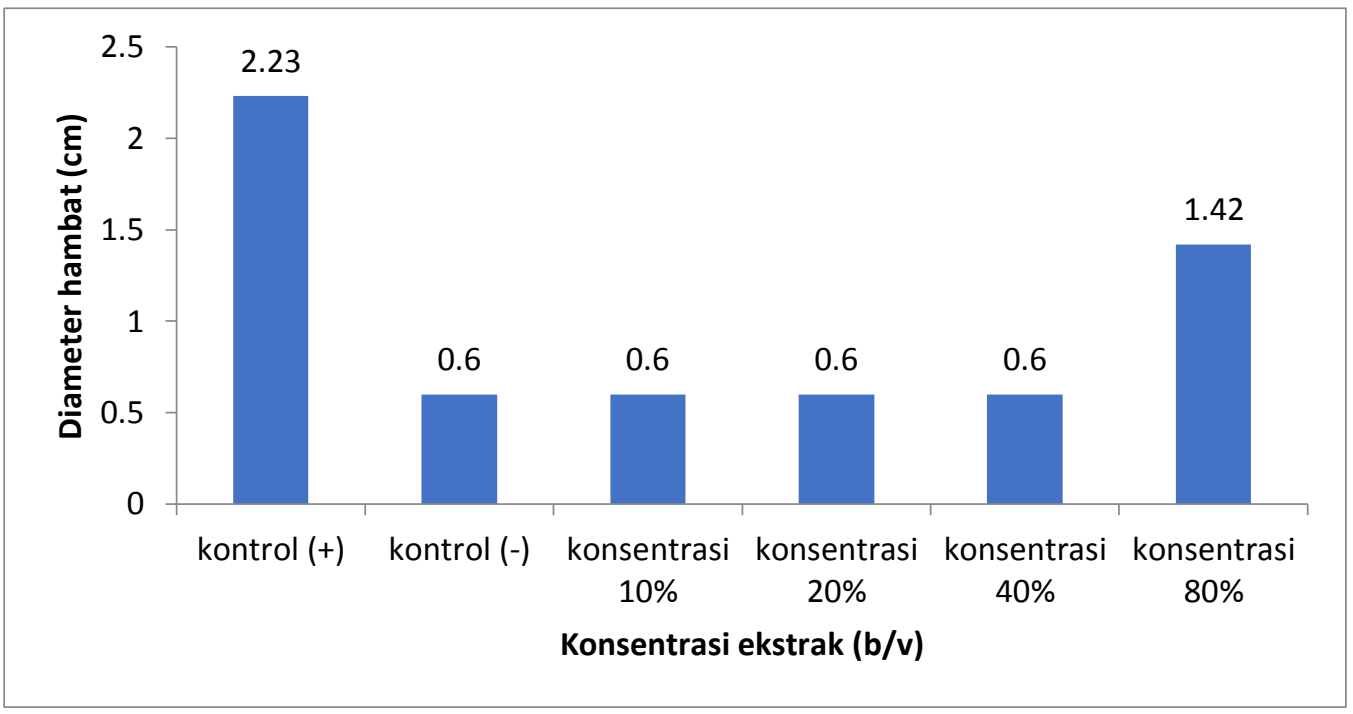

\section{Gambar 1. Diameter hambat ekstrak etanol daun suji (Pleomele Angustifolia N. E. Brown) terhadap pertumbuhan Staphylococcus aureus}

Berdasarkan tabel 1 diatas, didapat hasil bahwa ekstrak etanol daun suji pada konsentrasi $10 \%, 20 \%$, dan $40 \%$ tidak mempunyai aktivitas sebagai antibakteri terhadap bakteri Staphylococcus aureus karena tidak terdapatnya zona bening pada konsentrasi tersebut, tetapi pada konsentrasi $80 \%$ terdapat zona bening dengan rata-rata diameter zona bening sebesar $1,42 \mathrm{~cm}$. Hasil penelitian ini berbeda dengan hasil penelitian sebelumnya yang dilakukan oleh Andarini dkk (2012) dimana pada penelitian Andarini dkk ekstrak etanol daun suji memiliki aktifitas antibakteri terhadap Staphylococcus aureus pada konsentrasi $25 \%$. Tidak adanya aktifitas antibakteri ekstrak etanol daun suji pada penelitian ini kemungkinan dipengaruhi oleh beberapa faktor seperti faktor lingkungan, persentase rendemen dan mutu ekstrak. Pada penelitian sebelumnya yang Andarini dkk tidak dijelaskan tentang proses pemekatan ekstrak sedangkan pada penelitian ini menggunakan pemekatan ekstrak dengan waterbath, sehingga ada kemungkinan rusaknya senyawa metabolit sekunder (flavonoid) yang dapat menghambat pertumbuhan bakteri karena pemanasan yang tinggi. Pemanasan yang tinggi dapat menyebabkan kadar flavonoid yang terkandung dalam daun suji berkurang. Karena pemanasan yang tinggi dapat menyebabkan kerusakan pada senyawa metabolit sekunder, karena sebagian besar senyawa metabolit sekunder bersifat termolabil dan sebagian lainnya bersifat termostabil (Cahyati, 2017). Pada penelitian ini diperoleh ekstrak kental dengan persentase rendemen sebesar $24,63 \%$ sedangkan pada penelitian sebelumnya yang dilakukan oleh Andarini dkk tidak dijelaskan presentase rendemen yang didapat.

Penelitian yang dilakukan Malinikova dkk (2013) terhadap tanaman Fragaria vesca dimana kandungan metabolit sekunder (flavonoid) pada tanaman yang tumbuh di dataran tinggi lebih rendah kandungan flavonoidnya dibanding tanaman yang tumbuh di dataran rendah. Perbedaan tempat tumbuh kemungkinan juga mempengaruhi zat antibakteri yaitu flavonoid yang terkandung dalam tanaman suji. Tanaman suji yang tumbuh di daerah A bisa jadi memiliki jumlah kadar flavonoid yang berbeda dengan tanaman suji yang tumbuh di daerah B. Daun suji yang digunakan pada penelitian ini berasal dari tanaman yang di tanam dan tumbuh di halaman rumah daerah Karang Kendal sedangkan tanaman yang oleh Andarini dkk berasal dari Jl. Raya Lenteng Agung Jakarta. Faktor-faktor yang tidak terkontrol juga berpengaruh terhadap kandungan zat aktif dalam tanaman seperti penyiraman, pemberian pupuk, pencahayaan dan faktor-faktor lainnya. Dengan banyaknya 
faktor yang tidak terkontrol, maka akan berpengaruh terhadap jumlah zat antibakteri yang terdapat di dalam tanaman yang dijadikan sampel.

Kontrol positif pada penelitian ini digunakan amoxicillin sebagai pembanding atau tolak ukur dalam menentukan kemampuan ekstrak dalam menghambat bakteri. Kontrol positif dapat juga sebagai kontrol prosedur, apakah prosedur kerja dan tahapan uji yang dilakukan sudah sesuai atau belum. Diameter zona hambat kontrol positif (amoxicillin) terhadap pertumbuhan bakteri Staphylocoocus aureus memiliki nilai rata-rata $1,65 \mathrm{~cm}$ dengan konsentrasi $0,001 \% \mathrm{~b} / \mathrm{v}$. Diameter zona hambat tersebut masih lebih besar dibandingkan dengan rata-rata konsentrasi $80 \%$ ekstrak daun suji (Pleomele Angustifolia N.E Brown) yang hanya memiliki rata-rata zona hambat sebesar $1,42 \mathrm{~cm}$. Kontrol positif tujuanya berguna sebagai pembanding atau tolak ukur dalam menentukan kemampuan ekstrak dalam menghambat bakteri. Berdasarkan hasil penelitian ini ekstrak etanol daun suji (Pleomele Angustifolia N.E Brown) data yang diperoleh hanya satu yang menunjukkan kemampuan menghambat pertumbuhan bakteri Staphylococcus aureus maka data yang diperoleh tidak dapat dilanjutkan ke perhitungan regresi linear dan hipotesis apakah peningkatan konsentrasi berpengaruh terhadap daya hambat tidak dapat dijelaskan.

\section{KESIMPULAN}

Ekstrak etanol daun suji (Pleomele angustifolia N. E. Brown) dapat menghambat pertumbuhan bakteri Staphylococcus aureus hanya terdapat pada konsentrasi $80 \%$ yaitu sebesar $1,42 \mathrm{~cm}$, sedangkan pada konsentrasi 10\%, 20\%, 40\% tidak dapat menghambat karena tidak adanya daerah zona bening.

\section{DAFTAR PUSTAKA}

Alafiah, D.T. 2015. Uji aktifitas antibakri ekstrak etanol pelepah tanaman pisang ambon (Musa pradisiaca) terhadap bakteri Escherichia coli ATCC 11229 dan Staphylococcus aureus ATCC 6538. SECARA IN VITRO. Naskah publikasi. Fakultas kedokteran. Surakarta. Fakultas kedokteran, Universitas Muhammadiyah.

Andarini, D., Darmono., Tati, A. 2012. Uji Aktivitas Antibakteri Ekstrak Daun Suji Terhadap Staphylococcus aureus dan Shigella sp. Jakarta: Universitas Pancasila.

Andriani, R. Rizqi, P. Zulfa, E. 2018. Aktivitas Anti Bakteri Daun Suji (Pleomele agustifolia N.E Brown) Pada Bakteri Staphylococcus mutans. Jurnal Ilmiah Cendekia Eksakta.

Cahyati, U. 2017. Uji Aktivitas Antibakteri Ekstrak Etanol Daun Afrika (Vernonia amygdalina Del) Terhadap Pertumbuhan Bakteri Escherichia coli.Skripsi. Fakultas Kedokteran, Universitas Diponegoro.

Depkes. 1995. Materia Medika Indonesia Jiliid VI. Jakarta: Departemen Kesehatan Republik Indonesia.

Entjang, I. 2003. Mikrobiologi dan Parasitologi. Bandung: Citra Aditya Bakti

Eugelella, A, V. 2016. Hubungan Antara Pengetahuan Ibu Dengan Pembarian Amoxicillin Pada Balita. Surabaya: Universitas Airlangga.

Gupte, S MD. 1990. Mikrobiologi Dasar Edisi 3. Binarupa aksara. Jakarta.

Hanani, E. 2014. Analisis Fitokimia. Jakarta: Penerbit Buku Kedokteran EGC.

Ibrahim, T., Opwale, B., Oyoniloye, J. 2011.Uji Aktivitas Antibakteri Ekstrak Etanol Tanaman Obat Suku Musi. Sumatra Selatan: Universitas Sriwijaya.

Jawetz, E., Melnick, J. L., \& Adelberg, E. A. 2010. Riview Of Medical Microbiology. Jakarta: Buku Kedokteran EGC.

Lemmens, R.H.M.J \& N. bunyapraphatsara. 2003. Plant resources of South-East Asia Medical and Poisonous Plants. Leiden: Bachuys Publishers: 175-177

Lenda, V., Toelle , N, N.2014. Idwntifikasi dan Karakteristik Staphylococcus sp dan Streptococcus sp. Kupang: Politeknik Pertanian Negri Kupang 
Malinikova, E., J. Kulka, M. Kuklova, and M. Balazona, 2013. Altitudinal Variation of Plant Traits: Morphological Characteristics in Fragaria Vesca L. (Rosaceae). Annals of Forest Research 56, no. 1: 79-89.

Pratiwi, S, T. 2008. Mikrobiologi Farmasi. Jakarta: Erlangga

Radji, M 2008. Buku Ajar Mikrobiologi Panduan Mahasiswa Farmasi \& Kedokteran. Jakarta: EGC 
